\title{
A Grammar for Transformative Urbanism
}

\section{Sony Pellissery and Juliana Gómez Aristizábal}

\subsection{INTRODUCTION}

What does the future look like for Southern urban praxis? Writing at a time when global governance institutions are weak (even unable to respond collectively to survival questions such as those posed by a worldwide pandemic) and populist politics is gaining traction within national borders, the whole project could be seen as reactionary (or opportunist) in the current prevailing political climate. However, the quest for Southern models in urban planning has a history of at least two decades long. Its burgeoning literature has arrived at a consensus on the need for context-specific theories that signals a transition from a "Euclidian world order of stable entities" to the emergence of a "non-Euclidian world of many space-time geographies" (Friedmann, 1993, p. 482). In this

\author{
S. Pellissery $(\bowtie)$ \\ Institute of Public Policy, National Law School of India \\ University, Bengaluru, India \\ e-mail: sonyp@nls.ac.in \\ J. Gómez Aristizábal \\ Center of Urban and Environmental Studies, EAFIT \\ University, Medellín, Colombia \\ e-mail: jgomez5@eafit.edu.co \\ (C) The Author(s) 2021
}

A. K. Mohan et al. (eds.), Theorising Urban Development From the Global South, https://doi.org/10.1007/978-3-030-82475-4_11 
chapter, we move away from "either Euclid or nothing" to a grammarian alternative as one of the Southern models in urban planning.

The aspects that make Southern cities distinctive have remained illegible to scholars (Schindler, 2017). The dominant theories that have attempted to understand Southern processes evidence their struggle to comprehend the multiple urban processes that constitute the Southern territories-labelling them interesting, but anomalous (Roy, 2009) or abnormal (Robinson, 2006). Several of the existing models are useful for creating a new city or for managing urban agglomerations, so here we must make a distinction: both creating and managing may avoid creating discontinuities to the urbanism. However, apart from the planning functions of creating and managing, Southern models need to be transformative-challenging and modifying the urban space that perpetuates the status quo of social relations. ${ }^{2}$

To identify the grammar of transformative urbanism already latent in the Global South, we use three types of material as we develop arguments in this concluding chapter: firstly, the conclusions drawn in different chapters in this book, which are synthesized towards our arguments; secondly, contributions from several academics and practitioners of urban-planning practices in the Global South; thirdly, the accounts of urban vision by political leaders and public intellectuals of the Global South. These materials are woven together around the identification of the grammar that builds the transformative model, which is explained across three sections of the chapter. The first of these sections lays out a foundation for the distinctive grammarian approach, and its potential for theorizing Southern praxis. The second section shows how a communicative model (of autopoiesis) would produce space. Here, we propose three processes that could advance transformation processes of cities. In the third section, we attempt to spell out the characteristics of a grammar suitable for transforming Southern cities.

\subsection{A Grammar for the Tower of BABEL ${ }^{3}$}

In this section, we show how grammar as a model could provide alternative ways of conceptualizing urban praxis compared with the prevailing optimization techniques, which are based on formal rationality. The ability to pick up codes latent in a culture and in societal norms provides 
an edge for the grammar model to be context specific. We will also identify the commonality of experiences of urbanism in the South, which calls for a language and communication for transformation.

\subsubsection{Towards a Grammar}

Unitary forms of knowledge have long been challenged within the socialscience tradition. The most vocal of these challenges have come from feminism (Oakley, 2000) and subaltern studies (Spivak, 1988). ${ }^{4}$ The cultural-regional unit as the subject of knowledge construction is also well known (Said, 1978; and see the Asian value debate opposing humanrights hegemony in de Bary, 1998; also worth noting is the topic of indigenous knowledge movement). ${ }^{5}$ These challenges have now been taken seriously by several scholars of urban planning in order to create alternative spaces of theorization. What is problematic with unitary notion is its claim of universality of knowledge (Connell, 2007), which shapes practice in the areas of urban design, governance, and planning laws. In turn, this universality creates an epistemological framework highly imbalanced in favour of Global North (and English-speaking) territories (Stiftel \& Mukhopadhyay, 2007; Yiftachel, 2006).

Leisering (2021), attempting to theorize Southern social question, identifies four distinct methods: (a) applying theories or conceptual frameworks developed in a Northern context to the new context-namely, the Global South; (b) designing new theories and concepts in a grounded manner from the South; (c) adapting the Northern theories by respecifying them for Southern conditions and contexts; (d) beginning with Northern theories, but aiming to create a general theory that would suit both South and North. In the process, theory itself becomes respecified. Though Leisering does not say so, it is possible to have a fifth method whereby the process described in the fourth type is reversed (beginning with the South). "Southern-turn" literature in urbanism has attempted all of these approaches - some valiantly, others feebly. The learning gained from such experimentation is what McFarlane (2011) calls "assemblage". ${ }^{6}$ We adopt the fifth model in this chapter in order to uncover the transformative grammar that we are trying to illuminate here.

Urban development-as an area to which the disciplines of anthropology, geography, political science, urban planning, development studies, law, sociology, and economics have contributed to sustaining Southern 
theorizing - is a challenge inasmuch as these disciplines' core precepts come from the North-West. Therefore, as Oakley (2000, p. 75) puts it, "'Scientific' ways of knowing developed within a set of pre-existing dualisms which generated the conclusion that, so far as the liberation of the less powerful is concerned, science must almost always be an evil impulse". But urbanism is an experience strongly influenced not by scientists but by the practices of professionals, elected municipal authorities, business houses, courts, and citizens. It is in this sense that doors open for theory building for urban praxis from the South.

An objective construction of urban space, or the city as an engineered product, will benefit from a nomothetic approach towards knowledgei.e. one that aims to generalize. Searching for the perfect, transferrable model is a characteristic of this nomothetic process. On the other hand, ideographic approaches aim to specify. People in the city (and their meaning) matters here, and city is seen as a process. ${ }^{7}$ It is for this reason that we argue for a moving away from the science of cities to a grammar of cities. A grammar of the cities represents an ideographic approach, as it is a way to understand the urban condition beyond general/generic laws and to incorporate the diversities and simultaneous, conflicting realities that come together in the production of space in the Global South. But is there a system to this approach?

Comparable with Euclid's third century BC systematization of knowledge and the way in which it germinated a Western philosophical system, in the East, similar systematization of knowledge took place under Panini in the area of the Sanskrit language (fourth century BC) ${ }^{8}$ Panini's rules are (unlike Euclid's) derived non-deductively. The emphasis is on parsimonious arrangement (Chakrabarti, 1997). Similar context-specific particularism is observable in Indian philosophy when its scriptures are carefully analysed; Judaeo/Christian ethics of universal principles is not found there. Ramanujan $(1989$, p. 46) quotes Hegel to drive home this point: "While we say, 'Bravery is a virtue', the Hindoos say, on the contrary, "Bravery is a virtue of the Cshatriyas'". Southern theorization should find a grammar to unite these particularistic, context-sensitive rules.

In example after example, Scott (1998) has shown how grand projects of planned cities and towns collapsed when the abstract and generalized models of the state and technical agencies failed to incorporate practical knowledge already present in the society and local communities. ${ }^{9}$ There is a clear, semantic gap between the planner and those who are being 
planned for and our aspiration is to bridge this divide. At the same time, the language thereby created should not be hegemonic. As diverse as the countries in the South, the rules of the language should avoid being artificially systematic in order to bring all diversities under one fold:

Reaching an understanding in language places a subject matter before those communicating like a disputed object set between them. Thus the world is the common ground, trodden by none and recognized by all, uniting all who talk to one another. [...] For this reason invented systems of artificial communication are never languages. For artificial languages, such as secret languages or systems of mathematical symbols, have no basis in a community of language or life; they are introduced and applied only as means and tools of communication. For this reason they always presuppose a prior agreement, which is that of language. [...] In a real community of language, on the other hand, we do not first decide to agree but are always already in agreement. (Gadamer, 1975/2013, pp. 462-463)

The community referred to here comprises those who experienced epistemic and ontic Southern urbanism. Therefore, a prerequisite for developing a grammar is unravelling that experience.

\subsubsection{The Rebel Is from the South}

The introductory chapter in this book has argued how the use of the term "South" is not merely a geographical project. In this respect, a foundational text written a century ago (Gramsci, 1926/1978)-The Southern Question - is highly relevant. For Gramsci, the poor peasants of Southern Italy experienced themselves as colony of the country's North. It is in this sense the "south" transcends geographic categorization by reclaiming status while being pushed to periphery. How a citizen of India situated in Bengaluru responds to Delhi, how a Chinese citizen situated in Hong Kong responds to Beijing, or how a citizen situated in Rio de Janeiro responds to the more populous São Paulo or to the actual Brazilian capital of Brasília are all functions of how "south" is a representation for being away from the centre of power. In other words, geographical proximity could be one of the limitations for exercising the right of "speaking truth to power".

The function of the Southern rebel is prophetic. Their moral courage emanates from the fact that they are located on the periphery rather than 
at the centre. Thus, they can challenge the dominant models. The grammarian model thus challenges the "central-place theory" latent in urban models and aims to decentre (in the next section, we will show how an autopoietic model has no centre). In the words of Sanyal (2007), this is the Foucauldian role reversal of excluded subjects (of the "ship of fools") carrying out the redemptive function: "The stone which the builders refused has become the head stone of the corner" (Psalm 118: 22). The words of Chinese military leader Lin Piao ${ }^{10}$ demonstrate this concept:

Taking the entire globe, if North America and Western Europe can be called "the cities of the world," then Asia, Africa and Latin America constitute "the rural areas of the world." Since World War II, the proletarian revolutionary movement has for various reasons been temporarily held back in the North American and West European capitalist countries, while the people's revolutionary movement in Asia, Africa and Latin America has been growing vigorously. In a sense, the contemporary world revolution also presents a picture of the encirclement of cities by the rural areas. In the final analysis, the whole cause of world revolution hinges on the revolutionary struggles of the Asian, African and Latin American peoples who make up the overwhelming majority of the world's population. (Piao, 1965)

The starting point for rebellion is an awareness of the "wretchedness" of oneself (Fanon, 1961). This dissatisfaction with sub-optimality acts as the driver in a search for an alternative world. ${ }^{11}$ In the Latin American context, Zea (1953, p. 121) analysed the double movement of first turning to European solutions for the region's cities and then turning back to itself, away from the "corrupted western culture" and the importance of a shift to a culture that Latin America could call its own:

The [Latin] American people had to solve their problems quickly and one of the solutions was offered by the European culture and they adopted this type of solution. Currently, the European culture has become a problem instead of a solution, a burden instead of a support, the ideas that were so familiar to the Latin American people turned into sinister objects, unknown, dark and dangerous. It is in this context that [Latin] America needs a culture of its own, Latin American people have to solve their problems in a different way, it cannot be through imitation but through their own personal creation. 
The expression "urban Naxals" has been popularized in India recently to indicate those individuals who do not fall into line with the ideologies of the ruling state. "Naxalism" historically was associated with rural areas, ${ }^{12}$ wherein the feudal power of landholding and other agrarian resources was challenged by a conscientized proletariat. By transplanting this category to urban areas, space was designated as ideationally polluted and generated "unwanted" or "ugly" or "dangerous" individuals. Transformation begins with those who rebel against the status quo. Southern experience is looking for this radical change, and not the "Ptolemization" of adding complications in order to effect minor changes (Zizek, 2008, p. vii) to existing urban models.

Having outlined the basic tenets of the grammarian approach, and the unique experience of Southern cities that raises a need for the search for such a method, we now turn to the ways in which place-making occurs through communication models.

\subsection{The Autopoietic Production of Space}

Henri Lefebvre's The Production of Space has shown how the Hegelian notion of production was interpreted by Marx as "seeking rationality immanent to production". Therefore,

all productive activity is defined less by invariable or constant factors than by the incessant to-and-fro between temporality (succession, concatenation) and spatiality (simultaneity, synchronicity). This form is inseparable from orientation towards a goal - and thus also from functionality $[\ldots]$ and from the structure set in motion [...]. (Lefebvre, 1991, p. 71)

The vehement influence of this rationality-backed organization and the production of space on planning theory is problematic from a Southern perspective. It pushes into oblivion values of aesthetics, identity, morality, harmony, sociocultural practices, and sustainability - which are of central importance to the South. ${ }^{13}$ The reductive emphasis towards economism of production of space enables a "narrow definition of the problem at hand". Such a process helps in turning complex/wicked problems into manageable/solvable particulates (Dunn, 2004). Its use for managing already-created institutions by tweaking here and there cannot be denied; at an ideational level, this approach could also be useful for creating a new set of rules or institutions by keeping reductive economism as a 
benchmark. However, it is neither useful for transforming the space (the already-created institutions), and definitely a roadblock when searching for a Southern model.

Are there models, then, in which the underlying rationality claimed by the production of space is challenged? To answer this, we need to look at the constructs that brought the rational model into the field of planning in the first place. Escobar (1992) rightly points out that "urban planning" was a response to the invention of the ideas of economy and population in the eighteenth century. The application of laws of statistics, and the "normalisation" of human behaviour in large aggregates were part of this rationality project ${ }^{14}$ (Arendt, 1958).

Our search for models in which subjects have production capacity (without rationality as immanent, as per Lefebvre's quote above) led us to the theory of autopoiesis, proposed by Chilean biologists Humbarto Maturana and Francisco Varela $(1975,1980,1992)$. Their theory has been expanded as social-system theory by Niklas Luhmann (2002). ${ }^{15}$ Autopoiesis is basically a communication model ${ }^{16}$ in which units transform and destruct through self-referentiality. Heavily critical of rationalitybacked European enlightenment processes, Luhmann articulates what is known as "system rationality" - that is, the capability to provide a better understanding of complexity. In our search for a grammarian model, the centrality of communication that autopoiesis offers is invaluable. It is good to be aware of the fact that the autopoietic model could provide an alternative to globalized languages and official planning recipes, which promote norms and regulations that exogenously impact on people's livelihoods in neglected urban areas (Anguelovski et al., 2019; Schwab, 2018).

System rationality, facilitated through the autopoietic communication model, allows us to imagine designing cities that could think and could have moral character. In the remainder of the current section, we outline this model. We do this by expanding and prescribing three key process requirements:

(1) insurgent citizenship, already established in the planning literature of the South;

(2) planning models to promote urban dialectics; and

(3) generative urban designs, which have a three-decade-long history in the planning literature of the North, and which dovetail with the concept of order in philosophies from the Global South. 
Autopoiesis, which is a self-organizational model, could be infused with transformative urbanism if these three processes are used to generate grounded vocabularies (Mohan in the introductory chapter to this volume).

\subsubsection{Insurgent Citizenship: From "zombie" Cities to Thinking Cities}

Three global instruments operate to globalize cities: (1) financialization ${ }^{17}$; (2) knowledge transfer through consultancy firms ${ }^{18}$; and (3) benchmark making. ${ }^{19}$ These three processes together produce generic spaces (almost like a mould merely duplicating the master form). This is the technocratic, allopoietic process (the opposite of an autopoietic process) that makes cities look alike. Such places do not respond to the social stimuli of the people living there and become "zombie" cities. To combat this, we consider Holston's (1995) insurgent citizenship as one of the essential components of the grammar for transformative urbanism. We will not elaborate since the literature on this is evidently clear ${ }^{20}$ (see summary in Miraftab, 2016; also see Pellissery \& Lodemel, 2020). Several case studies presented in this volume show resistance to gravitation to be visible in the planning map.

The sheer diversity of the cities of the Global South presents an opposing reality to the usual homogenizing practices and the rigidity of the planning framework. Banerjee (Chapter 3 ) presents a highly relevant argument regarding the dynamics of globalizing cities that do not include all the diverse and discrepant pieces in the mosaic, that are locked into a relationship of co-dependence, and that struggle to deliver the commons to all citizens: public goods and services, safety and security, the opportunity to grow and prosper.

Another chapter in this volume covers the case of Lagos (Lawanson, Chapter 10) and discusses the irrelevance of the Nigerian city's planning framework in the face of the activities of religious organizations, especially Pentecostal churches, that have been reconfiguring the space without regard for the existing planning regulations. Like in many informal neighbourhoods of the Global South, Pentecostal communities in Nigeria have become major agents in the production of space-even replacing state planning agencies in some cases in order to realize their own futureoriented visions of the urban good (De Boeck, 2013; Hancock \& Srinivas, 2008). In this sense, the production of space operates outside formal 
planning mechanisms ${ }^{21}$; however, it uses the logic of homogenized urban reality (invisibilization, imposition, displacement, redevelopment, gentrification, etc.) in order to tailor the city to the religious community's needs and economic aspirations. In this particular case, religious communities have filled the void left by the state and its lack of control through its regulatory planning framework.

In this context of state absence and the irrelevance of planning, Chapter 6 (Calderón) reflects on the global challenge of socio-spatial justice within geographies of conflict, which produces the long-standing urbanization patterns that have accelerated the formation of marginal settlements in the steep hillsides of Medellín-often not officially recognized due to their lack of "formality". This condition leads the communities of these marginal settlements to processes of mobilization that contest their invisibility.

From the urban fringes of Medellín to the Shapira neighbourhood in southern Tel Aviv, communities in impoverished areas living without the state or under the shadow of planned radical change (Yiftachel \& Cohen, Chapter 7) are in constant mobilization. They need to be in this state in order to secure recognition and to resist the homogenizing logic that acts as a set of guidelines for rapid development and property speculation, with little regard to their impact on the everyday livelihood and the heterogenous dynamics of production and occupation of the spaces concerned. The authors affirm that in cities of the Global South with constant inflows of newcomers, deprived of much of their security and the means to make the most of the urban space, the pressure on urban administrations to formulate more inclusionary policies is acutely evident.

Can urban planning incorporate these inclusionary demands? From the perspective of transformative urbanism, a more challenging question is whether architecture and master plans could generate sublimation or the basic interactive process of transformation. Our view is that elements of order need to be decoded from their cultural contexts in order to understand the prerequisites for coding architecture with the potential for sublimation. We take this theme up after we deal with the form of interaction/dialogue required for urban planning-urban dialectics. 


\subsubsection{Urban Dialectics}

Dialectical urbanism is [the] singular ability to illuminate how the modern city can be both an administratively structured "objective" site or [a] forcefield of planned relations and a reflexively structuring "subjective" space of collective dwelling, improvising, appropriating, dreaming, innovating, struggling and transforming. (Lewandowski, 2005, p. 294)

Our examination of voices in the South in this book has clearly demonstrated a tendency of planning language to be dialectical. We consider this a second process requirement for transformative urbanism.

At the foundational moment of the Indian Republic, after the country's independence in 1947, three Indian leaders held completely different views on urban development. Mahatma Gandhi, celebrated as the father of the nation, thought that India lived in villages and, from a moral point of view, opposed urbanization as a strategy. ${ }^{22}$ Bhimrao Ambedkar, the leader of India's historically Untouchable community and chairman of the drafting committee of the Constitution thought exactly the opposite: "What is a village but a sink of localism, a den of ignorance, narrowmindedness and communalism?" For Ambedkar, urbanization was the answer to ending the iniquities of the caste system: in such spaces, inter-caste dining and inter-caste marriage would be plausible. Compared with these two visionaries, Jawaharlal Nehru, the first prime minister of the country, believed in European-style town planning, and brought in French-Swiss architect Le Corbusier to make master plans for Indian cities. At the same time, Nehru also saw how cities and villages were intimately connected. If India has truly escaped totalitarian planning, it is the dialectic demonstrated above that has made this possible. The three leaders here are not fetishizing the object of urban: they are placing the idea in its historical context. Hundreds of resistance movements against evictions and master plans in India have imbibed their spirit from this process of dialectics.

Running counter to urban dialectic is metaphysics, and the Euclidianengineered product called "city". On the other hand, urban dialectics is able to imagine continuity between universal abstraction and its particular use. This view is most articulately expressed in the statement of the Standing Committee of the National People's Congress of China (1989): 
City planning must suit the specific conditions of our country and embody a correct handling of the relationship between short-term and long-term development. The principle of usefulness and economy and of building the country through thrift and hard work must be adhered to in construction in a planned urban area. ${ }^{23}$

With this political aspiration, the Chinese planning system finds a synthesis within which to work with market-oriented reforms (Abramson, 2007).

McFarlane and Silver (2017) note that dialectics is an everyday experience in resolving contradictions in the city life of Kampala (Uganda). Similarly, Uruguayan writer, academic, and literary critic Rama (1982) finds that cities are places of transculturation that produce syntheses of continental dimensions and the influence of foreign cultures. Rama showed the emergence of a new set of thinking beyond the simple reception of exogenous ideas, and this condition led to a historical connection that fusions of ideas create a new element enriched by diverse sources. To Rama, transculturation is the recovery of Latin American tradition and its singularity.

\subsubsection{Generative Urban Designs}

The third process that we suggest for facilitating transformative urbanism has been elaborated on by Alexander et al. (1987) in their A New Theory of Urban Design. The authors reject the model of urban planning in which the final form is prescribed. Rather, they suggest sequential steps that will generate designs. Let us first consider a contrasting case presented in this volume, before we delve into what generative designs could offer.

The case comprises what Liu and Wang (Chapter 5) present regarding the planning system in China. China's urban-planning experience is unique among the Global South countries. Its system was created from scratch and it was extensively influenced by the West; however, China's urban planning does not function as a political process. By institutional design, it functions as a technical process that is embedded in an authoritarian political system. While this planning system has been remarkably successful in serving the needs of rapid economic growth, urbanization, and rising living standards, it has not been fast enough in safeguarding the environment and the interests of people-especially the disadvantaged. The homogenizing practices led by a planning system that serves an authoritarian state's aspirations of modernity have configured urban 
spaces like "copycat" towns and gated communities, and have promoted the urban-village style of redevelopment with its very weak bottom-up channel.

Contrast the Chinese case with Yiftachel's and Cohen's (Chapter 7) concept of defensive urban citizenship (DUC). This type of urban membership is shaped through processes embedded in proliferating urban threats that are born of market-led policies, intertwined with identity regimes to cast a shadow of "temporariness" on most residents of the urban frontier. The threat of displaceability produces the self-mobilization of residents in order to defend their imperilled social and material spacesand, in the case of the Shapira neighborhood-their housing rights and "turf". These new alliances are created to resist hegemonic attempts to divide and conquer and, instead, promote working together to fend off looming threats.

What do these two contrasting cases offer for understanding the grammar of transformative urbanism? A key difference is the notion of centre. In the Chinese case, centre and the legitimacy of its plans are accepted; it is rejected in the Shapira model. Generative designs rebuff the notion of "centre" as a point. Rather, "a field of centers, then, is a nested series of localities that frame one another and variously connect to one another in a pattern of relationships" (Mehaffy, 2008, p. 60). At the core of this concept is the philosophical notion that Alexander (2003) called The Nature of Order - and it is in this idea of order that language meets planning. The main property of linguistic systems is discontinuity, the existence of a series of differential elements without a centre. In such an arrangement, each word has a centrality of its own. At the same time, between each element, there is space that creates discontinuity. We will show how the ideas of order in the South dovetail with Alexander's ideas of generative designs.

"The City has its order and the Village its custom". This Javanese proverb summarizes the modernist politics of city making described by Scott (1998, Chapters 2 and 4). The fact is that in most of the cities of the Global South, once their veneer of modernity is removed, a deep desire for customs emerges. In other words, Southern urban planning becomes an exercise in antinomies of culture (if we import planning notions from the North), but operating with huge imbalances.

In several Asian religions and philosophies, the notion of order overlaps with those of truth and goodness. Hinduism, Jainism, Buddhism, and Daoism all conflate fitting behaviour, or harmony, and order in peculiar 
ways. In the Vedic scriptures, rta is placed above the gods, who adhere to cosmic laws; the creative power of the gods emerges from this adherence to $r t a$, and humans can participate in this creative power through the correct performance of rituals. Daoism also speaks of a similar harmony, wherein the individual is able to "understand and forget" distinctions yet maintain a balance (of yin and yang) of essential unity.

There have been attempts to codify these principles into rules. For instance, $r t a$ (cosmic changing order) as a concept is opposed to dharma (established moral rules). To reconcile this contradiction, dharma is prescribed differently for different subjects (king, worker, elderly person, young person, etc.). In other words, order should progress in a particular manner; a general manner of order would not convey the meaning required and would defy aesthetics.

In Latin America, three pairs of discursively opposing concepts- "indigenist" and "pachamamist" (which prioritizes identity as an objective), "socialist" and "statist" (which prioritizes equity), and "ecologist" and "post-developmentalist"-flow together to constitute the ideals of good living (Hidalgo-Capitán \& Cubillo-Guevara, 2017). These ideals have contributed both to the revolutionary movements and the constitutional processes in different countries of the region. ${ }^{24}$

These are examples of ways in which order exists without a point of centre in the Global South. Such systems require the generating of designs viewed from the perspective of each element.

In this section, we have discussed three mediating communication processes (insurgent citizenship, dialectics, and generative designs) required to advance the production of space through system rationality. In the next section, we will discuss micro and meso experiences specific to Southern cities, to which these three processes need to be applied in order to allow transformative cities to emerge.

\subsection{Transformative Cities}

Latin American thinker and pedagogue Paulo Friere provides the outline for the process of transformation:

Thus, it is not the limit-situations in and of themselves which create a climate of hopelessness, but rather how they are perceived by women and men at a given historical moment: whether they appear as fetters or as insurmountable barriers. As critical perception is embodied in action, a 
climate of hope and confidence develops which leads men to attempt to overcome the limit-situations. This objective can be achieved only through action upon the concrete, historical reality in which limit-situations historically are found. As reality is transformed and these situations are superseded, new ones will appear, which in turn will evoke new limit-acts. (Freire, 1970, p. 99)

In this final section of the paper, we outline how the elements of grammar for transforming cities are connected with each other. Figure 11.1 summarizes this outcome. Three core precepts (decolonize, decommodify, and delegalize) are symbiotically connected in Southern urbanism.

The colonial experience is closely linked to state formation in many countries in the Global South that have replaced their indigenous legal systems (Comaroff \& Comaroff, 2006) and initiated the commodification of natural resources, labour, and money (Polanyi, 1944). It is not possible to transform cities by addressing only one of the aforementioned

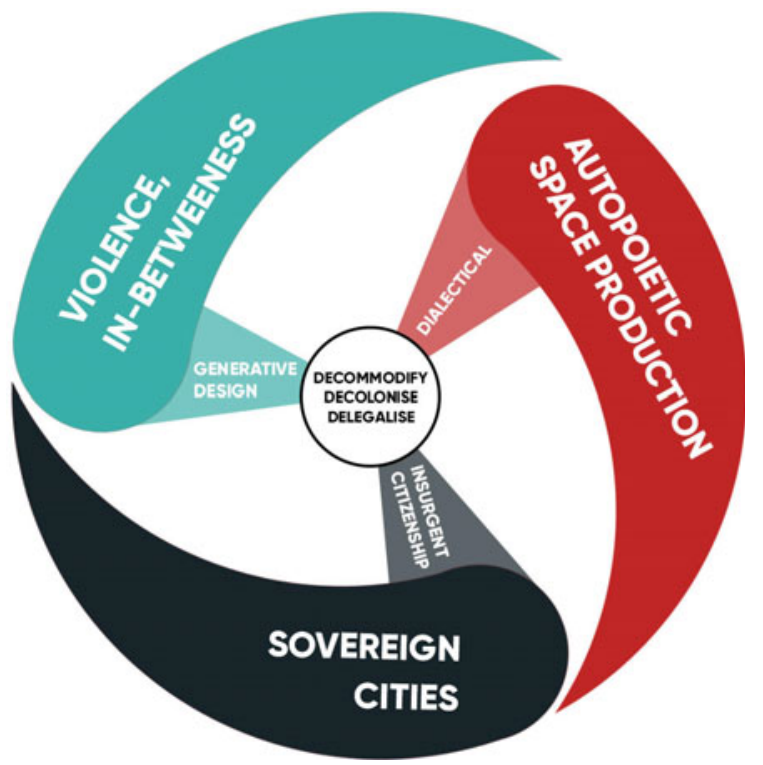

Fig. 11.1 Communication model for transformative urbanism (Source The authors) 
precepts - decolonizing, decommodifying, and delegalizing; all three have to operate simultaneously. The words of Lee Kuan Yew (Singapore's premier 1959-1990) are insightful in this regard:

When we were confronted with an enormous problem of bad housing, no development, overcrowding, we decided that unless drastic measures were taken to break the law, break the rules, we would never solve it. We therefore took overriding powers to acquire land at low cost, which was in breach of one of the fundamentals of British constitutional law-the sanctity of property. But that had to be overcome, because the sanctity of the society seeking to preserve itself was greater. (Centre for Liveable Cities, 2016, p. 10)

In different historical, geographical, and knowledge contexts, these precepts have different hermeneutical exhortations.

To call for decommodification is to deploy urban resources in such a manner that partnerships between citizens are generated (Squires, 2011): things are not valued over people. To call for decolonization today is to liberate ourselves from the captive minds that fail to usher the resources from within. To call for delegalization is to prevent reified institutions from erecting obstacles to the transformative power of peoples' collectives.

This core is the wellspring from which the three mediating communication processes explained in the previous section emerge. In the context of urban planning, it takes the form of the autopoietic production of space. We consider this to be meso-level modality, connecting microlevel experiences of citizens (such as in-betweenness and suffering) with macro-level urban aspirations (urban sovereignty). In this section, we will elaborate on these micro and macro elements. However, we consider the meso process - which has been explained in the previous section- to be the most important one.

\subsubsection{In-Betweenness as a Transformative Moment}

One of the most powerful methods of Euclidian systematization was zerosum thinking. Wittgenstein (1958) warns against such substantialization, since both speech and thought are likely to be off the track and unable to specify the particular context. Compared with that system, several philosophical schools in the Global South maintain that the absolute has no 
qualities, and that therefore it is without substance. ${ }^{25}$ Lefebvre (1991, p. 254) has shown the Christian influence on European urban planning, whereby "absolute space was identified with subterranean space [i.e. the cemetery]". Unlike the absolute space of the crypt, consider the Hindu practice of cremating the dead body and spreading its ashes in a river: within the philosophical tradition of birth and rebirth, the bodily existence is seen as temporary-and thus as a rejection of the absoluteness of space.

Unlike zero-sum thinking, the experience of in-betweenness is transformative. Urbanism provides such "eureka" moments resembling the Platonian Allegory of the Cave: within the limits of given space and time, the subject is able to see another possibility that liberates it from those limits ${ }^{26}$-hence, the yearning for the new reality (that is, not just the utopian Garden City), to which one is exposed. A concrete example is provided by circular migration in the cities of the Global South. Breman (1996), through his in-depth observation of the migration patterns in India, has shown that it is circular in nature-i.e. temporary and repetitive movement between host city and home town/village. Escaping from the feudal structures of the village, the migrant experiences the anonymity in the slums of megacities. Going back to the villages, he/she has acquired the courage to challenge those feudal values. Back (again) in the city, the subject experiences transient jobs, employers, and snobs struggling to catch up with an alien culture. ${ }^{27}$

This condition of simultaneity and complexity in the way in which space is understood and produced in the cities of the Global South allows us to overcome the vision of these geographies as merely problematic or pathological (Schindler, 2017). Banerjee in this volume (Chapter 3) presents the intersection of traditional, sociocultural orders and the modern, urbanized lifestyles alongside which they exist. The case of the urban villages in Delhi is labelled a home-grown modernity, in which traditional village life intermixes and assimilates "order" and "customs" (explained in the previous section here) into a single transformative reality. The introductory chapter to this volume also refers to this experience as an in-betweenness of homogeneity and heterogeneity. 


\title{
11.4.2 Suffering and Violence
}

Upon inviting a European friend to visit India, his honest response was, "I had been to India once, but don't want to go there again. It takes several weeks to get back to myself after people beg me money on the streets and witnessing terribly distressed lives". This is same for most of the Global South's cities, marked by highly visible inequality. Simone expressed it thus:

\begin{abstract}
African cities don't work, or at least their characterizations are conventionally replete with depictions ranging from the valiant, if mostly misguided, struggles of the poor to eke out some minimal livelihood to the more insidious descriptions of bodies engaged in near-constant liminality, decadence, or religious and ethnic conflict. A more generous point of view concedes that African cities are works in progress, at the same time exceedingly creative and extremely stalled. In city after city, one can witness an incessant throbbing produced by the intense proximity of hundreds of activities: cooking, reciting, selling, loading and unloading, fighting, praying, relaxing, pounding. (Simone, 2004, p. 15)
\end{abstract}

Several Latin American scholars have described this marginality differently. ${ }^{28}$ Castells developed a significant part of his hypothesis about the "urban question" in Santiago de Chile during the 1960s, in a context of political agitation and people's claims for urban housing alternatives. Castells talked about "marginality" from the perspective of a high level of social organization (even higher than in other areas of the city). It offered an alternative model opposed to the prevailing urban theories. Castells affirmed that the Latin American city was important in understanding the interdependence between the "marginal" and "modern" urban realities, and how important it was to recognize conflict in order to produce disruptive guidelines as alternatives to the dominant social order (Castells, 1974, p. 89).

Violence and suffering have primarily been viewed through a Northern lens. Salahub et al. (2018) have filled this vacuum by looking at cities from a Southern perspective. They find that violence cannot be separated from the questions of both social structure (identity that creates conflicts between communities, or even the patriarchal nature of cities perpetuating crime on women) and urban infrastructure (segregated settlement patterns and class-based discriminated access to city infrastructure such as malls). This is how suffering and violence becomes a foundational experience of urbanism in the Global South. ${ }^{29}$ 


\subsubsection{Uvban Sovereignty}

Prior to Westphalia, the city had its own autonomous existence. It was a place sought after because of geographical advantage (e.g. a port, good climate) as well as agglomeration effects-a network economy, in which entrepreneurs enjoyed proximate access and networking of businesses that created knowledge externality (see Mohanty, 2014). Even colonial powers came in order to both take and give cities. ${ }^{30}$ As Westphalia drew national borders, it was a matter of evolution that cities would be placed within national boundaries. Jacobs puts this process succinctly:

Nations are political and military entities, and so are blocs of nations. But it does not necessarily follow from this that they are also the basic, salient entities of economic life. [...] try looking at the real economic world in its own right rather than as a dependent artifact of politics, we can't avoid seeing that most nations are composed of collections or grab bags of very different economies, rich regions and poor ones within the same nation. $[\ldots]$ We can't avoid seeing, too, that among all the various types of economies, cities are unique in their abilities to shape and reshape the economies of other settlements, including those far removed from them geographically. (Jacobs, 1984, pp. 31-32)

Cities took a double blow-once through the nationalization project of Westphalia in the seventeenth century, and then again through the globalization project of the twentieth century. Several national leaders viewed the creation and development of cities in the colonial period as being opposed to national objectives, and the policy responses emanating from such an assessment were hugely different from their predecessors. Some polities attempted to completely reverse to the precolonial era; many other polities attempted a balancing of regions through the creation of "rurban" regions; some others wanted cities to prosper, and to redistribute their wealth by remaining connected to villages; yet others viewed cities as the future, and created policies biased towards densification and urbanization.

Julius Nyerere (President of Tanzania 1964-1985) thought that urbanization, which had been brought about by European colonialism, was economically driven by wage labour. This had disrupted the traditional, precolonial, rural African society. He believed that it was possible for his government to recreate precolonial traditions in Tanzania and, in turn, re-establish a traditional level of mutual respect and return the people 
to settled, moral ways of life (Boddy-Evans, 2019). Tanzania's "villagization" movement and establishment of a new capital away from Dar es Salaam need to be seen in this context. ${ }^{31}$

Disparity between cities and villages was a political question within the nationalization project. ${ }^{32}$ Simultaneously, inequality within the city limits raised another set of problems. How that inequality had to be dealt was a national question, rather than something to be managed within cities. ${ }^{33}$ The integration of cities into the nation was a political project. ${ }^{34}$

The second blow to cities' sovereignty came through the globalization project. In Khatua's text (Chapter 2), the suburbs are the spaces where globalizing forces operate, becoming instruments of governance in the Kolkata Metropolitan Area. In this area, the state's drive to make the city part of the global capital circuit has led to a loss of agricultural and natural resources through the formation of new towns and the re-delineation of municipal borders that are guided by market and state logic, which is disconnected from the communities concerned. In the earlier part of this paper, we have explained three global processes that make "zombie" cities.

A transformative city should be able to nurture political participation beyond a formal legal autonomy. In India, Chatterjee speculates that the lack of intellectual engagement with improving urban conditions may have to do with a "perceived lack of agency by the Indian elite in thinking about the city" (Chatterjee, 2004, p. 140). The city was seen as a colonial invention, to which the Indians had adapted; they did not belong there. Even when the urban middle class began asserting its moral influence on the city in the 1950s and 1960s, it did not go so far as acknowledging a position of authority over the "Western" city.

The urban sovereign model is a macro space of citizen interaction that is coherent with the autopoietic system of self-referential closure. Without this autonomy, the city could become politically subservient to the actors, ideas, and institutions, which would signal homogenizing tendencies.

\subsection{CONCLUSION}

"Beyond the ideas of right and wrong, there is a beautiful garden. I shall meet you there. When the soul lies down in that garden, world is too full to talk about". Sufi poet Rumi's words summarize the search for a model beyond the rationalities of planning. A rational model could still be relevant for creating a new city or even to manage the urban 
agglomeration, retaining the optimality principles. Unless the underlying assumption of the rational model of planning changes, however, both creation and management can only multiply the existing problems of Southern urban areas. It is for this reason that we have, in this chapter, argued for the transformative function of planning.

The emancipation of urban existence in the Global South requires a recognition that the region's authenticated social order is essentially problematic. The autopoietic production of space as an interaction between the natural and social orders, left to itself, would not lead to any transformation. This is where rearrangement without an emphasis on the "centre" could initiate a transformative process. Codes latent in societal norms need to be identified, and a process of using these codes to destroy and transform planning is required. We have identified three processesinsurgent citizenship, urban dialectics, and generative designs-which could be used to shape this autopoietic process. These three processes have the potential to move the autopoietic production of space towards emancipation.

For those engaged in these situated modernities, the call for action therefore lingers louder than the cry for independence, as the aim is not a "private liberation" but a collective takeover of an urban life based on a grammar of transformative urbanism for and from the South.

\section{Notes}

1. Friedmann (1993) proposed five characteristics of non-Euclidian planning: normative, innovative, political, transactive and one based on social learning.

2. Transformation as a concept has its own legacy in social-science literature. A summary, and an account of its philosophical roots in Critical Realism, can be found in Bhaskar (1986).

3. We use this metaphor from Genesis (Chapter 11) to hold this chapter together in the search for an overarching theory for hugely diverse contexts.

4. Feminists points out the 'masculinisation' of the character of science; subaltern literature contends that science is distant from the common people.

5. Though there is no scope for a full treatment of the epistemology of this tradition in this paper, a brief overview is useful. The debate between objectivist and relativist understanding lies at the heart of this clash. Khun (1962) and Winch (1958) attacked objectivism, with is strong roots in 
the positivist tradition. Feyerabend's (1975) epistemological anarchism opened the Pandora's box of relativism in its fullest sense, leading to a widening gap between objectivism and relativism. This yawning gulf between scientific traditions gave important headway for practitioners. What emerged was the realization of the multiple standards of rationality (Bernstein, 1983). Thus, the paradigm of practice was not dependent on one standard or another but rather on bringing completeness or closure of understanding through many observations and inferences emerging from multiple contexts (Brunner, 2006). In other words, diverging conclusions emerging from many models would enhance understanding rather than pathologizing it. Dependence on a single model by practitioners led to reductionist and context-independent understanding. At the height of such thought, Rorty (1978) rejected representational accounts of knowledge and language; he held that even the best of the scholarship achieves only the holding up of a 'mirror towards $[. .$.$] nature'.$

6. See also empirical evidence of the green-city model of Hanoi as an assemblage (Leducq and Scarwell, 2020).

7. "[...] objects in cities-whether they are buildings, streets, parks, districts, landmarks, or anything else-can have radically different effects, depending upon the circumstances and contexts in which they exist. Thus, for instance, almost nothing useful can be understood or can be done about improving city dwelling if these are considered in the abstract as 'housing'. City dwelling-either existing or potential-are specific and particularized buildings always involved in differing, specific processes [...]." (Jacobs, 1961, p. 440)

8. See the systematic comparison of both methods - of Euclid and Paniniby Staal (1965).

9. Scott used the expression metis, and some other planning scholars (for example, Flyvbjerg, 2001) have used the term phronesis.

10. Lin Piao, as a field commander of the Red Army, contributed to the Communists' 22-year struggle for power and held many high government and party posts. He played a prominent role in the first few years of the Cultural Revolution (1966-1976).

11. Particularly notable is the opinion of one Japanese public intellectual:

I'm not satisfied with the fundamental ideas of the Japanese people. Japanese who have travelled to the West think that if they only put into practice the external forms of factories, governments or anything else, then they can make a fine civilization with that alone. If they just bring back the form, then what good is that without the substance? This is Japan's civilization today. Because we don't look at the substance of true civilization, because we don't understand 
it, because we don't feel it, Japan's importation of European civilization has truly reached the extremes of unsightliness. [...] I think that as long as the Japanese take no notice of the substance of civilization, no matter how they may adorn it with beautiful external forms it will be of no use at all. (Nagai Kafu quoted in Schulz 2011, p. 148)

12. The term "naxal" comes from a village in the eastern part of IndiaNaxalbari-where a peasant revolt was first staged in 1967. The insurgency movement also has a close connection with the Communist Party in India.

13. Planning literature from the Global South recognizes conflicting rationalities (see Watson, 2003 for the conflict between governmental rationality and survival rationality). Yet, planning experts are challenged to explore alternatives to the rationality project.

14. There is no need to summarize here the various criticisms of the application of human-rationality models in practical problem solving. Sociologists and anthropologists (Max Weber and Mary Douglas, to name but two who have distinguished between rational and rationalizing) who have attempted to understand how rationality operates in human decisions have become sceptical of the endeavour itself. The moral intuitions are more foundational than strategic reasoning (Haidt, 2013).

15. Autopoiesis is one of the ideas marginalized by planning experts (see Assche \& Verschraegen, 2008).

16. The opposite of autopoiesis is allopoiesis, similar to how production in a factory takes place-using raw materials, something different is created (a computer, a car, etc.).

17. Caldeira (2006) gives the example of how Brazil became the largest borrower from the World Bank primarily for urban infrastructure, and how this created improvements as well as deterioration in social lifeincluding the proliferation of favelas, the reduction of social mobility, and an increase in violence. In a similar manner, Xaxa's chapter in this volume (Chapter 4) shows how a yearning for private capital in the form of landed property in the Indian city of Ranchi led to the destruction of a traditional bond between the local communities and homogenizing logics being applied to the Indigenous population.

18. Master-plan creation is a job outsourced by the municipalities of the Global South to international agencies, which often have access to finer data-even to the scale of square metre of a street.

19. Indexes such as the "Roster of World Cities", "Global Cities Investment Monitor", and "Innovation Cities" are examples of such benchmarking exercises. 
20. In one of the chapters in this volume, a related concept-defensive urban citizenship - is introduced as an alternative approach to understanding the city and its communities' engagement in the production and reconfiguration of their space. Through the case of southern Tel Aviv (Yiftachel \& Cohen, Chapter 7) shows how self-mobilization led to the integration of different types of populations (immigrants, veterans, foreigners and young people) into a new urban community. This could be seen as a vista point from which to understand the transformation of most contemporary cities of our time. Mendez-Abad (Chapter 8) demonstrates how insurgent urban citizenship is also useful in understanding the process of public-space re-appropriation in Guayaquil, in which, beyond the tensions emerging from diverse interests in the informal neighborhood of El Cisne Dos, the community worked together in order to reclaim and adapt the public space to their needs and everyday practices.

21. The informal economy can be viewed as a highly sophisticated network system based on trust, in which non-state welfare realization is achieved (Davy \& Pellissery, 2013)—although "seeing [it] like a planner/state", it would seem to be merely chaotic and unorganized. The autopoietic model offers an explanation for the informal economy rather than seeing it as something that cannot be understood. Therefore, contrary to Roy's (2009) argument of informality as an impediment to urban planning, the autopoietic model would argue that it is our failure to understand the codes of informality that leads us to fail to incorporate the same into planning models.

22. Gandhi wrote, in his 1909 book Hind Swaraj, or "Indian Home Rule",

Machinery is like a snake-hole which may contain from one to a hundred snakes. Where there is machinery there are large cities; and where there are large cities, there are tram-cars and railways; and there only does one see electric light. English villages do not boast of any of these things. Honest physicians will tell you that where means of artificial locomotion have increased, the health of the people has suffered. I remember that when in a European town there was a scarcity of money, the receipts of the tramway company, of the lawyers and of the doctors went down and people were less unhealthy. I cannot recall a single good point in connection with machinery.

23. As shown in this chapter, the Global South is diverse and totalitarian planning is visible in several parts of the region. China is a good example: Deng Xiaoping, who is credited with leading China towards modernization as well as with developing the city of Shenzhen, noted, 
From the very outset there were different opinions concerning the establishment of special economic zones, fearing whether this meant practicing capitalism. Shenzhen's construction achievements have answered those having worries of one kind or another, the special zone is "socialist", not "capitalist" in nature. ("Records of Comrade Deng Xiaoping's Shenzhen Tour", published by the People's Daily)

24. In the African context, too, we could find similar notions of order:

African towns and cities were at once utilitarian, ornamental, and humane. They symbolized not only man's relationship to his fellow man and the cosmos but man's adaptation to the natural environment. Rather than conquer and destroy nature, the African builder revered and complimented it. Moreover, urban living radiated a spirit of mutual aid and cooperation, of civility and gentility, of good manners and etiquette. There was a sensitive interrelatedness to everything; and it was that quality that made African towns and cities, and the structures within them, works of art. (Hull, 1976, p. 78)

25. See Staal (1965) for evidence of the same in Chinese and Indian philosophy. In the Chinese language, there is no word that corresponds to "to be". In Sanskrit thinking, the absolute as substance is considered as category confusion with the particular.

26. This experience has been theorized better in the philosophy of art, in the contexts of the paintings of Rembrandt van Rijn (1606-1669) or Diego Velázquez (1599-1660).

27. Some cities have tried to historicize the in-between experience of the city by presenting the "journey of the city" to its population. Examples include the Migrant Workers' Library on the outskirts of Beijing and the Labour Museum in Oslo, Norway.

28. Hernando de Sotto's 2000 Mystery of Capital describes slum dwellers as entrepreneurs.

29. Delhi's annual murder rate per 100,000 persons is above 500 , while that of São Paulo is above 100. These figures are illustrative: across most Southern cities, rates of violence and crime are alarming.

30. Mumbai (then Bombay) was a dowry gift from Portugal to the British Crown in 1661 - of course, well after Westphalia (1648), when there was no Indian nation but the Kingdom of Portugal and the British Empire, with their boundaries clearly marked (not just Lisbon or London). 
31. It is also useful to take note of opposing, minoritarian views: "It is above all in these new urban societies that the characteristic institutions and ideas of African nationalism are born and grow to maturity" (Hodgin, 1956, p. 216).

32. Kakuei Tanaka, Japan's prime minister (1972-1974) articulated this coherently:

Public opinion calls for the simultaneous solution of overcrowding and under population to live in comfort in a beautiful land of affluence and security. To achieve these ends, we must boldly reverse this torrential urban concentration and direct our national energy and surplus economic strength to remodelling the entire archipelago. Disparity between urban and rural areas, between the prosperous Pacific coast and the stagnating Japan Sea coast, can surely be eliminated by using levers such as relocating industries, making them more knowledge intensive, constructing super-express railways and trunk expressways throughout the nation, and creating nationwide information and communication networks. (Tanaka, 1973, p. iv)

33. Lee Kuan Yew of Singapore said,

After independence in 1965, I was troubled by Singapore's completely urban electorate. I had seen how voters in capital cities always tended to vote against the government of the day and was determined that our householders should become home owners, otherwise we would not have political stability [...] I believed this sense of ownership was vital for our new society which had no deep roots in a common historical experience. (Yew, 2000, p. 167)

34. Mao's speech to Communist Party cadres in 1945 is instructive:

From 1927 to the present the centre of gravity of our work has been in the villages-gathering strength in the villages, using the villages in order to surround the cities and then taking the cities. The period for this method of work has now ended. The period of "from the city to the village" and of the city leading the village has now begun. The centre of gravity of the Party's work has shifted from the village to the city. In the south the People's Liberation Army will occupy first the cities and then the villages. Attention must be given to both city and village and it is necessary to link closely urban and rural work, workers and peasants, industry and agriculture. Under no circumstances should the village be ignored 
and only the city given attention; such thinking is entirely wrong. Nevertheless, the centre of gravity of the work of the Party and the army must be in the cities; we must do our utmost to learn how to administer and build the cities. (Tse-tung, 1949)

\section{REFERENCES}

Abramson, D. B. (2007). The dialectics of urban planning in China. In Wu. Fulong (Ed.), China's emerging cities (pp. 66-87). Routledge.

Alexander, C. (2003). The nature of order. Routledge.

Alexander, C., Neis, H., Anninou, A., \& King, I. (1987). A new theory of urban design. Oxford University Press.

Anguelovski, I., Irazábal-Zurita, C., \& Connolly, J. J. T. (2019). Grabbed urban landscapes: Socio-spatial tensions in green infrastructure planning in Medellín. International Journal of Urban and Regional Research, 43(1), 133-156.

Arendt, H. (1958). Human condition. University of Chicago Press.

Assche, K. V., \& Verschraegen, G. (2008). The limits of planning: Niklas Luhmann's systems theory and the analysis of planning and planning ambitions. Planning Theory, 7(3), 263-283.

Bernstein, R. J. (1983). Beyond objectivism and relativism. Penn Press.

Bhaskar, R. (1986). Scientific realism and human emancipation. Routledge.

Boddy-Evans, A. (2019). What was Ujamaa and how did it affect Tanzania? ThoughtCo. https://www.thoughtco.com/what-was-ujamaa-44589. Accessed 27 April 2021.

Breman, J. (1996). Footloose labour: Working in India's informal economy. Cambridge University Press.

Brunner, R. D. (2006). A paradigm for practice. Policy Sciences, 39, 135-167.

Caldeira, T. P. R. (2006). "I came to sabotage your reasoning!": Violence and resignifications of justice in Brazil. In J. Comaroff \& J. L. Comaroff (Eds.), Law and order in the postcolony (pp. 102-149). University of Chicago Press.

Castells, M. (1974). Estructura de clases y politica urbana en América Latina. Ediciones SIAP.

Centre for Liveable Cities. (2016). Urban redevelopment: From urban squalor to global city. Centre for Liveable Cities.

Chakrabarti, A. (1997). Rationality in Indian philosophy. In E. Deutsch \& R. Bontekoe (Eds.), A companion to world philosophies (pp. 235-240). Blackwell.

Chatterjee, P. (2004). Politics of the governed. Columbia University Press.

Comaroff, J., \& Comaroff, J. L. (2006). Law and disorder in the postcolony. University of Chicago Press.

Connell, R. (2007). Southern theory: Global dynamics of knowledge in social science. Polity Press. 
Davy, B., \& Pellissery, S. (2013). The citizenship promises (un) fulfilled: The right to housing in informal settings. International Journal of Social Welfare, 22, S68-S84.

deBary, W. T. (1998). Asian values and human rights: A confucian communitarian perspective. Harvard University Press.

De Boeck, F. (2013). The sacred and the city: Modernity, religion, and the urban form in Central Africa. In J. Boddy \& M. Lambek (Eds.), A companion to the anthropology of religion (pp. 99-112). John Wiley and Sons.

Dunn, W. N. (2004). Public policy analysis. Pearson.

Escobar, A. (1992). Planning. In W. Sachs (Ed.), Development Dictionary (pp. 132-145). Yale University Press.

Fanon, F. (1961). The wretched of the Earth. François Maspero.

Feyerabend, P. (1975). Against method. Verso.

Flyvbjerg, B. (2001). Making social science matter. Cambridge University Press.

Freire, P. (1970). Pedagogy of the oppressed. Herder \& Herder.

Friedmann, J. (1993). Toward a non-Euclidian mode of planning. Journal of the American Planning Association, 59(4), 482-485.

Gadamer, H. (1975/2013). Truth and method. Bloomsbury.

Gramsci, A. (1926/1978). Some aspects of the southern question. In Selections from political writings 1921-1926 (translated and edited by Q. Hoare). Lawrence and Wishart.

Haidt, J. (2013). The righteous mind. Vintage Books.

Hancock, M., \& Srinivas, S. (2008). Spaces of modernity: Religion and the urban in Asia and Africa. International Journal of Urban and Regional Research, 32, 617-630.

Hidalgo-Capitán, A. L., \& Cubillo-Guevara, A. P. (2017). Deconstruction and genealogy of Latin American good living (Buen Vivir). The (Triune) good living and its diverse intellectual wellsprings. International Development Policy, $9(1), 23-50$.

Hodgin T. (1956). Nationalism in colonial Africa (Man and Society Series). Frederick Muller, Ltd.

Holston, J. (1995). Spaces of insurgent citizenship. Planning Theory, 13, 35-51.

Hull, R. (1976). African cities and towns before the European conquest. Norton \& Company Inc.

Jacobs, J. (1961). The death and life of Great American cities. Vintage.

Jacobs, J. (1984). Cities and the wealth of nations. Vintage Books.

Khun, T. (1962). The structure of scientific revolutions. University of Chicago Press.

Leducq, D., \& Scarwell, H. (2020). Green-city models as an urban strategy: Hanoi between international practices and local assemblage. Town Planning Review, 91(4), 437-456. 
Lefebvre, H. (1991). The production of space (D. Nicholson-Smith, Trans.). Blackwell.

Leisering, L. (2021). Social protection in the Global South: An ideational and historical approach. In L. Leisering (Ed.), One hundred years of social protection (pp. 3-52). Palgrave Macmillan.

Lewandowski, J. (2005). Street culture: The dialectic of urbanism in Walter Benjamin's Passagen-werk. Philosophy \& Social Criticism, 31, 293-308.

Luhmann, N. (2002). Introduction to systems theory (P. Gilgen, Trans.). Polity.

Maturana, H., \& Varela, F. (1975). Autopoietic systems. University of Illinois Press.

Maturana, H., \& Varela, F. (1980). Autopoiesis and cognition: The realization of the living. D. Reidel.

Maturana, H., \& Varela, F. (1992). The tree of knowledge: The biological roots of human understanding. Shambhala.

McFarlane, C. (2011). Assemblage and critical urbanism. City: Analysis of Urban Trends Culture, Theory, Policy, Action, 15, 204-224.

McFarlane, C., \& Silver, J. (2017). Navigating the city: Dialectics of everyday urbanism. Transactions, 42(3), 458-471.

Mehaffy, M. W. (2008). Generative methods in urban design: A progressive assessment. Journal of Urbanism, 1(1), 57-75.

Miraftab, F. (2016). Insurgent planning: Situating radical planning in the Global South. In S. S. Fainstein \& J. Defilippis (Eds.), Readings in planning theory (pp. 480-498). Wiley Blackwell.

Mohanty, P. K. (2014). Cities and public policy. Sage Publications.

Oakley, A. (2000). Experiments in knowing. Polity Press.

Pellissery, S., \& Lodemel, I. (2020). Property and social citizenship. Social Policy and Society, 19(2), 275-292.

Piao, L. (1965). Long live the victory of people's war! https://www.marxists. org/reference/archive/lin-biao/1965/09/peoples_war/ch07.htm. Accessed 27 April 2021.

Polanyi, K. (1944). The great transformation. Beacon Press.

Rama, A. (1982). Transculturación narrativa en América Latina. Siglo Veinitiuno.

Ramanujan, A. K. (1989). Is there an Indian way of thinking? An informal essay. Contributions to Indian Sociology, 23(1), 41-58.

Robinson, J. (2006). Ordinary cities: Between modernity and development. Routledge.

Rorty, R. (1978). Philosophy and the mirror of nature. Princeton University Press.

Roy, A. (2009). Why India cannot plan its cities: Informality, insurgence and the idiom of urbanisation. Planning Theory, 8(1), 76-87.

Said, E. W. (1978). Orientalism. Random House. 
Salahub, J. E., Gottsbacher, M., \& Boer, J. (2018). Social theories of urban violence in the Global South. Routledge.

Sanyal, K. (2007). Rethinking capitalist development. Routledge.

Schindler, S. (2017). Towards a paradigm of southern urbanism. City, 21(1), 47-64.

Schulz, E. (2011). Nagai Kafu's reflections on urban beauty in Hiyorigeta: Reappraising Tokyo's back alleys and waterways. Review of Asian and Pacific Studies, 36, 139-164.

Schwab, E. (2018). Spatial justice and informal settlements: Integral urban projects in the Comunas of Medellin (1st ed.). Emerald Publishing Limited.

Scott, J. C. (1998). Seeing like a state. Yale University Press.

Simone, A. (2004). Introduction: Remaking African cities. In A. M. Simone (Ed.), For the city yet to come: Changing African life in four cities (pp. 1-20). Duke University Press.

Spivak, G. C. (1988). Can the subaltern speak? In C. Nelson \& L. Grossberg (Eds.), Marxism and the interpretation of culture (pp. 271-316). University of Illinois Press.

Squires, G. D. (2011). Partnership and the pursuit of the private city. In S. S. Fainstein \& S. Campbell (Eds.), Readings in urban theory (pp. 207-228). Wiley Blackwell.

Staal, J. F. (1965). Euclid and Panini. Philosophy East and West, 15(2), 99-116.

Standing Committee of the National People's Congress. (1989, December 26). The City Planning Law of the People's Republic of China. Adopted at the 11 th Meeting of the Standing Committee of the Seventh National People's Congress. Retrieved January 12, from, http://www.asianlii.org/cn/legis/ cen/laws/cplotproc422. Accessed 27 April 2021.

Stiftel, B., \& Mukhopadhyay, C. (2007). Thoughts on Anglo-American hegemony in planning scholarship: Do we read each other's work? Town Planning Review, 78(5), 545-572.

Tanaka, K. (1973). Building a new Japan; A plan for remodeling the Japanese Archipelago. Simul Press.

Tse-tung, M. (1949, March 5). Report to the second plenary session of the Seventh Central Committee of the Communist Party of China. Hsipaipo Village, Pingshan County, Hopei Province. https://www.marxists.org/reference/archive/ mao/selected-works/volume-4/mswv4_58.htm. Accessed 27 April 2021.

Watson, V. (2003). Conflicting rationalities: Implications for planning theory and ethics. Planning Theory \& Practice, 4, 395-407.

Winch, P. (1958). The idea of a social science and its relation to philosophy. Routledge.

Wittgenstein, L. (1958). Philosophical investigations. Basil Blackwell.

Yew, L. K. (2000). From third world to first: The Singapore story-1965-2000. HarperCollins Publishers. 
Yiftachel, O. (2006). Re-engaging planning theory? Towards 'south-eastern' perspectives. Planning Theory, 5(3), 211-222.

Zea, L. (1953). América como conciencia. Cuadernos Americanos. Versión de la Universidad Nacional Autónoma de México (UNAM). http://revistaliterari akatharsis.org/zea.pdf. Accessed 27 April 2021.

Zizek, S. (2008). The sublime object of ideology. Verso.

Open Access This chapter is licensed under the terms of the Creative Commons Attribution 4.0 International License (http://creativecommons.org/licenses/ by $/ 4.0 /$ ), which permits use, sharing, adaptation, distribution and reproduction in any medium or format, as long as you give appropriate credit to the original author(s) and the source, provide a link to the Creative Commons license and indicate if changes were made.

The images or other third party material in this chapter are included in the chapter's Creative Commons license, unless indicated otherwise in a credit line to the material. If material is not included in the chapter's Creative Commons license and your intended use is not permitted by statutory regulation or exceeds the permitted use, you will need to obtain permission directly from the copyright holder.

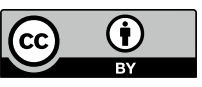

